extending to the base of the antennæ. The thoracic stripes are brown and narrower than in the male, the metanotum just below the scutellum white. The base of the first abdominal segment shows two depressed, subdorsal areas, base of the second and the fifth, sixth and seventh segments, and tip of the ovipositor, brown. The halteres and legs as a whole are slightly lighter in color and wings broader than in the male. Length the same, $8 \mathrm{~mm}$.

The male was described by Edward Burgess (Proc. Boston Soc. Nat. Hist., 1878, vol. 19, p. 320), from a specimen collected about 1872 near the U. S. Arsenal, Springfield, Mass., by Dr. George Dimmock. It was next captured by Mr. William Reiff near Ellis Station, Norwood, Mass., April 18, 1909 and recorded by the writer (Psyche, 1909, vol. 16, p. 132). ${ }^{1}$ It was again taken by Mr. Reiff April 21, 1912, and by the writer at the same locality, May 3, 1918. I have also received a specimen for determination from $\mathrm{Mr}$. H. L. Johnson, collected at South Meriden, Conn., April 17, 1915. Among the species of the family Xylophagidæ, Glutops singularis is not the only rare species. The following are represented only by single specimens in the collection of the Boston Society of Natural History: Arthropeas americana Loew, Cheshire, Mass., June 30; Rhachicerus nitidus Johns., Bar Harbor, Me., July 24; Solva aterrima, Johns., Franconia, N. H. (Mrs. Slosson); S. tenthredinoides v. d. Wulp, Bretton Woods, N. H., June 29; Xylophagus nitidus Adams, Mt. Washington (Mrs. Slosson); Ptiolina edeta Walk., “Alpine Garden," Mt. Washington, July 4. There is a single record for New England of two other species, Rhachicerus fulvicollis Halid., Beverly, Mass. (Edw. Burgess) and Xylophagus longicornis Loew, Mass., but neither are represented in the Society's collection.

\title{
Two Interesting Additions to the Odonate Fauna of Concord, Mass.
}

In the Entomological News (30:10-14, 1919) I published a list of eighty-seven species collected in Concord, Mass., and during the past spring $I$ have made two interesting additional captures:

Nasiaschna pentacantha (Ramb.) One male taken June 15, 1920, at Bateman's Pond. The second New England record,-I

\footnotetext{
1 In 1917, Mr. Arthur Gibson (47th Ann. Rept. Ent. Soc. Ont., 1916, p. 154), recorded this species from Agassiz, B.C., June 1915, collected by R. C. Treherne.
} 
having taken one at Moultonboro, N. H., on July 9, 1916 (see PSYCHe 24: 51, 1917), and a specimen has since been sent me taken at Dedham, Mass., by Miss Eleanor Clark on June 14, 1920. Dr. Needham I find also records its capture at Wellesley, Mass. (see Bull. Ill. State Lab. Nat. Hist. 6:34, 1901).

Tetragoneuria canis MacLach. Seven males taken on May 31 and June 2, 1920, at a small pond near the township border of Carlisle. The fourth New England record,--having been taken at Franconia, N. H., by Mrs. Slosson; at Jaffrey, N. H., by Mr. C. W. Johnson; and in Connecticut based on an undated and unstationed specimen in the collection of the Connecticut Agricultural Experiment Station at New Haven. This species only represented by males was almost common at this little pond on both dates. The pond is one that $I$ have visited every year regularly at this season for the past five or six years. All the other species found flying there were ones always noticed before. I am wondering whether the nymphs of $T$. canis transform every year or whether the larval stage may cover several years. An explanation of the presence of the species at the pond this year seems difficult to explain on other grounds.

Thoreau Museum of Natural History.

R. Heber Howe, Jr. 


\section{EXCHANGE COLUMN.}

Notices not to exceed four lines in length concerning exchanges desired of specimens or entomological literature will be inserted free for subscribers, to be run as long as may be deemed advisable by the editors.

Cynipidæ,- - galls or the bred makers, - of the world desired for exchange or purchase. Will determine North American material. Address: Alfred C. Kinsey, Bussey Institution, Forest Hills, Mass.

Wanted: Insects of any order from ant nests, with specimens of the host ants, from any part of the world; also Cremastochilinæ of the world. Will give cash or Coleoptera, Hymenoptera and Diptera from the United States.-Wm. M. Mann, U. S. National Museum, Washington, D. C.

Wanted: To exchange, or purchase for cash, specimens of the Genus Apantesis from any locality. Also to purchase rare Catocalæ.-Samuel E. Cassino, Salem, Mass.

Wanted for cash: Lowest representatives of all families of insects, preserved in fluid.-G. C. Crampton, Amherst, Mass.

Wanted: Syrphidx (Flower-flies) from all parts of the world. Exchanges solicited. Will determine on the usual conditions.-C. L. Metcalf, Ohio State University, Columbus, Ohio.

Largest Expanse-one each $\sigma^{x}$ and $\&$ Lepidoptera wanted for transfer purposes. Those not good enough for collections will do. Will buy, or exchange for local Lepidoptera, etc.-C. V. Blackburn, 12 Pine St., Stoneham, Mass.

Butterflies of Japan and Formosa, will be exchanged by S. Satake, 48 Aoyamaminamimachi 5-chome, Tokyo, Japan.

For Sale: Psyche, complete set, $\$ 40$. Volumes 3 to 20 , newly bound in 11 volumees, red half calf, with black cloth sides; also Ann. Ent. Soc. Amer., complete, \$12. Volumes 1 to 6 , newly bound in black half calf, cloth sides.-A. C. Hansen, 945 Margate Ter., Chicago.

For sale, or exchange for entomological items not in my library-American Entomologist, complete; Dyar, List of N. A. Lepidoptera; Redi, Experimenta, circa Generationem Insectorum, 1686; many others.--J. E. Hallinen, Cooperton, Okla.

Wanted: To examine, determine and exchange Cicadellidæ or "Jassidr" from all parts of North America.-J. G. Sanders and D. M. DeLong, State Capitol, Harrisburg, Pa.

Cochineal Insects: Wish to obtain living specimens of cochineal scales. Will purchase or exchange as may be desired.-C. T. Brues, Bussey Institution, Boston 30, Mass.

Wanted: Species of Rhynchophora from Eastern North America not represented in my collection, in exchange for duplicates from Indiana and Florida. Lists of desiderata and duplicates on application.-W. S. Blatchley, 1530 Park Avenue, Indianapolis, Ind. 

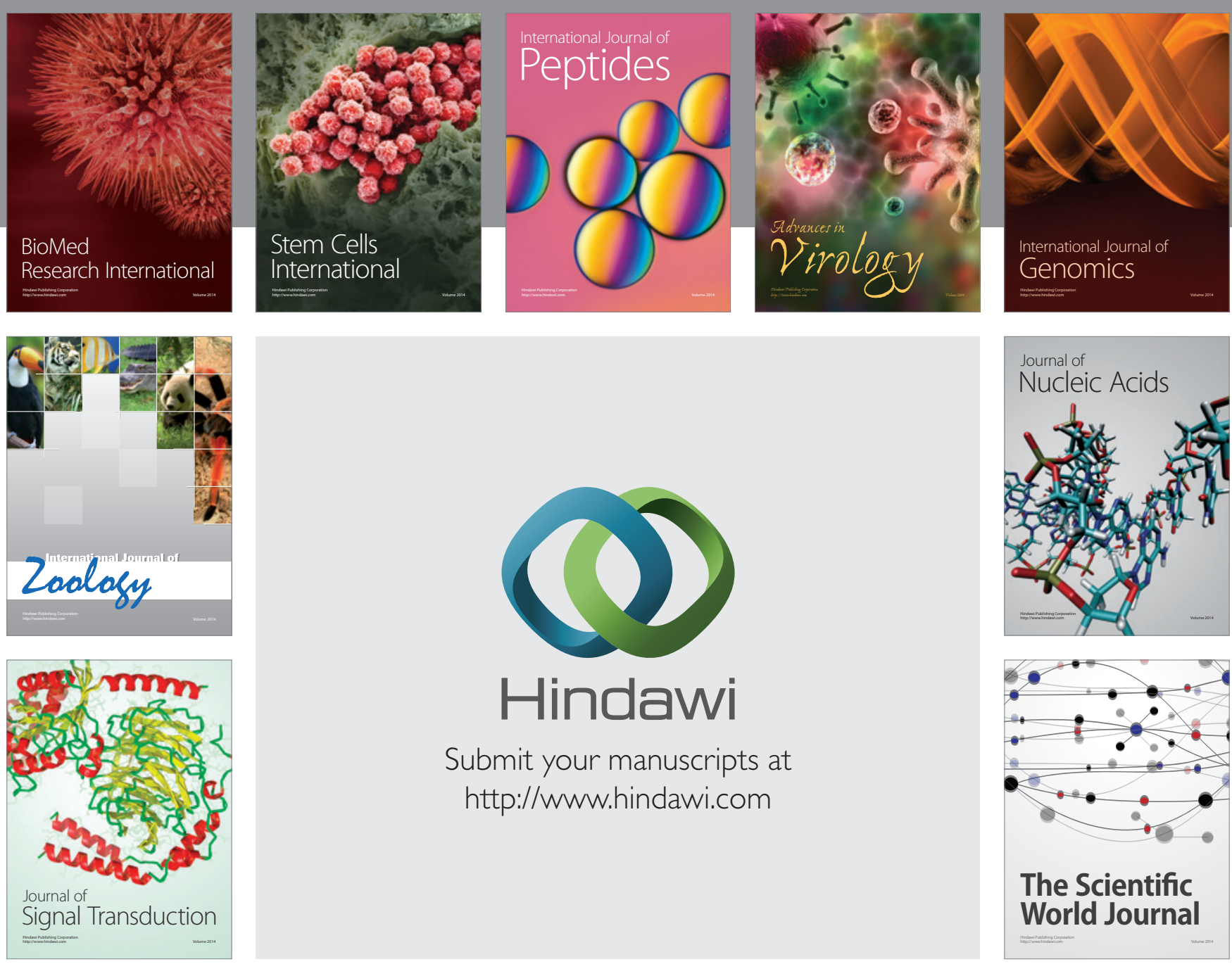

Submit your manuscripts at

http://www.hindawi.com
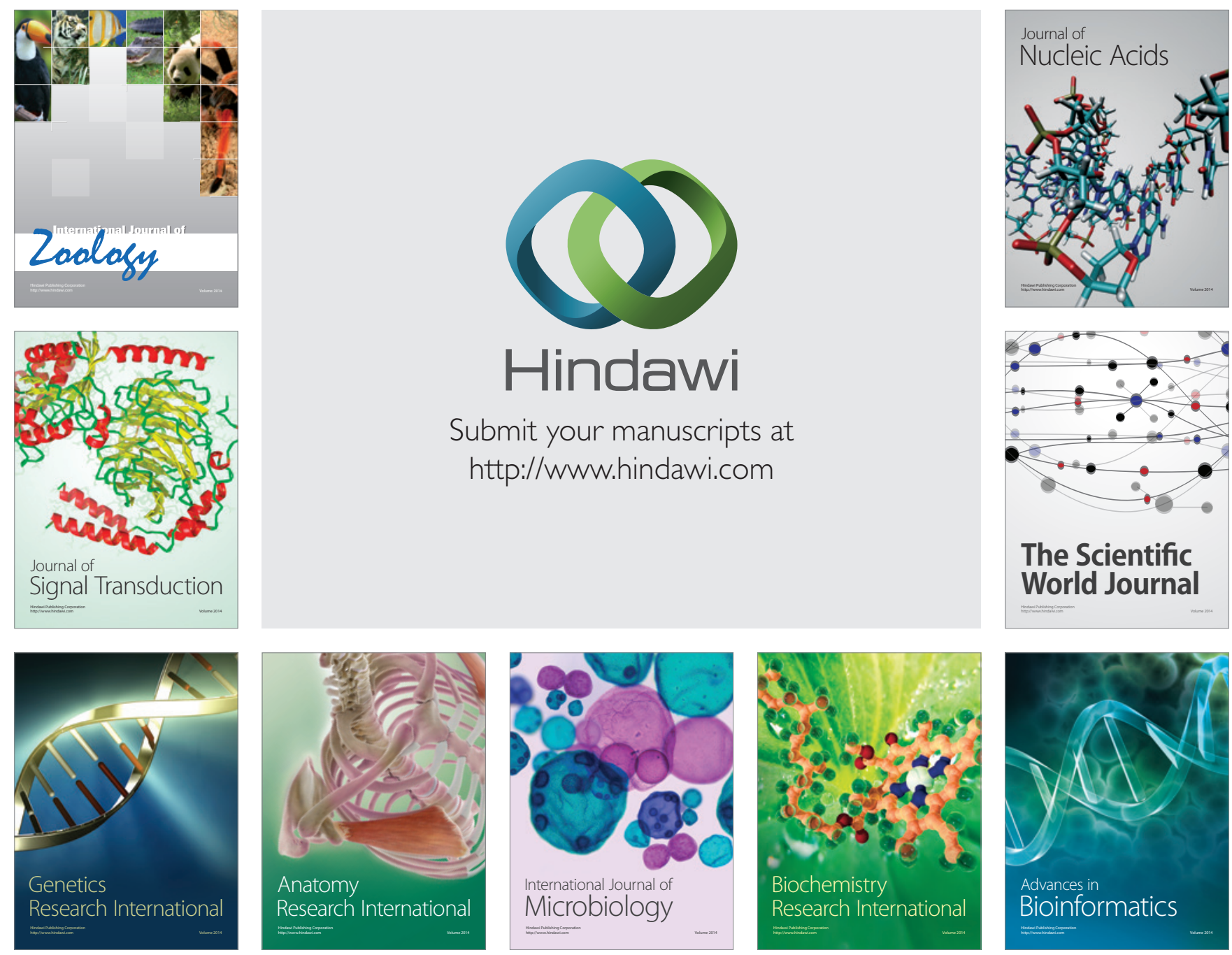

The Scientific World Journal
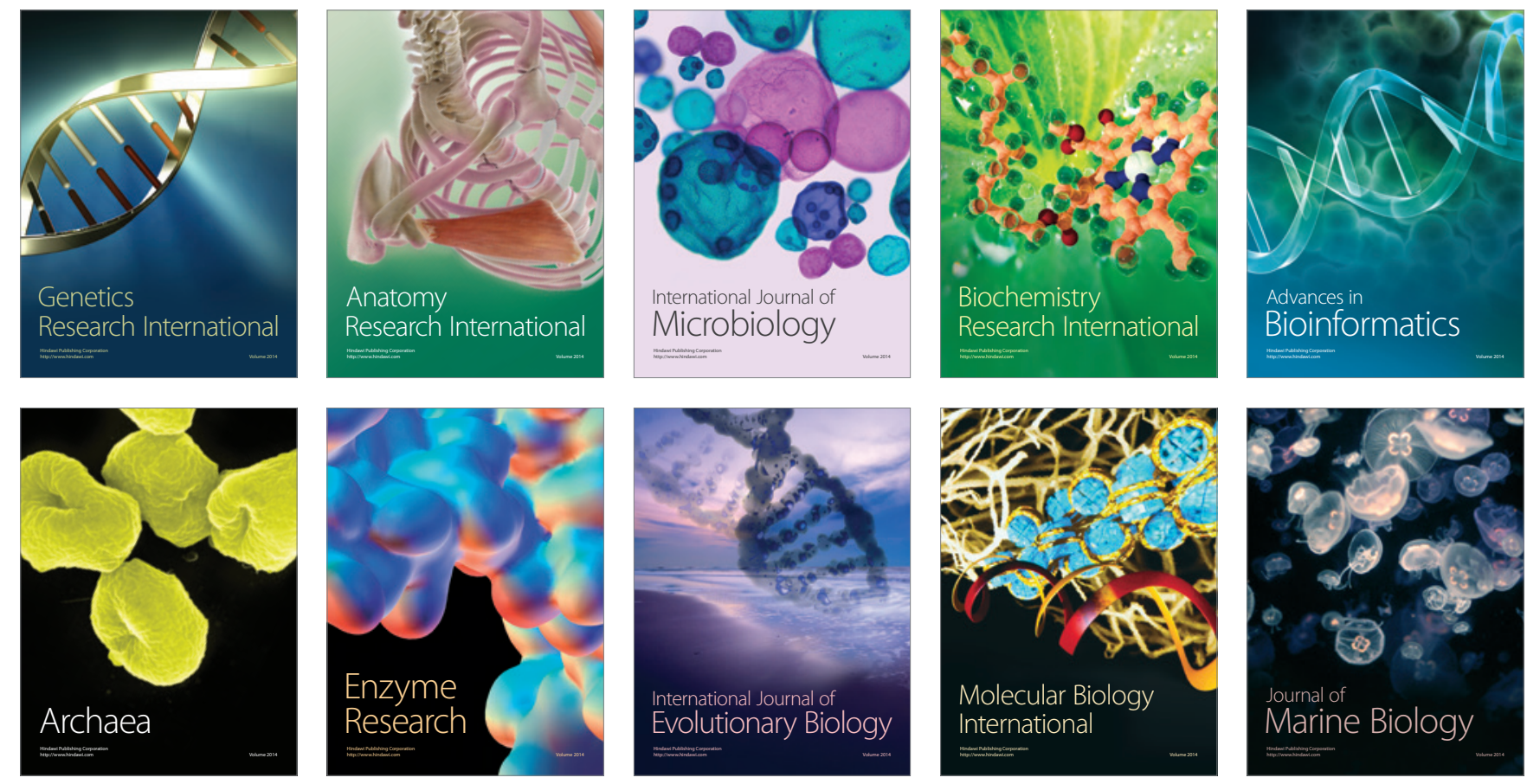